\title{
Menthol and eugenol as natural anesthetics for early juveniles of curimba
}

\section{Elias Fernandes de Medeiros Junior ${ }^{1}$, Silvio Akira Uehara ${ }^{2}$, Evelize Cristina Rodrigues ${ }^{3}$, Glauber David Almeida Palheta ${ }^{3}$, Nuno Filipe Alves Correia de Melo ${ }^{3}$, Lícius de Sá Freire ${ }^{2}$, Rodrigo Takata ${ }^{2,3^{*}}$ (iD}

\footnotetext{
${ }^{1}$ Instituto Federal de Educação, Ciência e Tecnologia do Amazonas, Campus São Gabriel da Cachoeira, São Gabriel da Cachoeira, AM, Brasil.

${ }^{2}$ Fundação Instituto de Pesca do Estado do Rio de Janeiro, Departamento de Pesquisa e Produção, Niterói, RJ, Brasil.

${ }^{3}$ Universidade Federal Rural da Amazônia, Programa de Pós-graduação em Aquicultura e Recursos Aquáticos Tropicais, Belém, PA, Brasil.
}

\begin{abstract}
The objective of this study was to evaluate menthol and eugenol as anesthetics for early juveniles of curimba, Prochilodus lineatus. Juveniles of $4.0 \pm 0.5 \mathrm{~g}$ and a total length of $8.8 \pm 0.1 \mathrm{~cm}$ were exposed to the anesthetics menthol (20, 30 , 40, 50, 60, 70, and $\left.80 \mathrm{mg} \mathrm{L}^{-1}\right)$ and eugenol $\left(20,30,40,50,60\right.$, and $\left.70 \mathrm{mg} \mathrm{L}^{-1}\right)$ up to deep anesthesia. The anesthetic effects were evaluated measuring the induction time to deep anesthesia (characterized by loss of equilibrium, absence of swimming, reduction of opercular movements, and responses only to intense tactile stimuli), recovery time, time to appetite return, and mortality rate after $96 \mathrm{~h}$ of procedure. The concentrations between 60 to $80 \mathrm{mg}$ of menthol $\mathrm{L}^{-1}$ provided the lowest time of induction. Increased concentrations led to a decrease in recuperation time. The concentrations between 50 to $70 \mathrm{mg}$ of eugenol L $\mathrm{L}^{-1}$ provided the lowest induction times; however, recovery time was not affected by eugenol concentrations. The return to appetite was observed $24 \mathrm{~h}$ after anesthesia, while the survival after $96 \mathrm{~h}$ was $>90 \%$. Concentrations of 60 and $50 \mathrm{mg} \mathrm{L}^{-1}$ of menthol and eugenol, respectively, are recommended for effective anesthesia with limited side effects.
\end{abstract}

Key Words: aquaculture, physiology, Prochilodus lineatus, stress

\section{Introduction}

In Brazil, anesthesia has been studied aiming to minimize stress and, thereby, decrease suffering of animals during handling procedures (Bertozi Junior et al., 2014; Ribeiro et al., 2015a,b). The concentration and efficacy required for induction may vary in relation to species, age, size, and water quality parameters (Walsh and Pease, 2002; Woody et al., 2002; Gomes et al., 2011).

Eugenol and menthol are among the main natural anesthetics used in aquaculture. Eugenol is a natural product obtained from the distillation of the extract of clove (Eugenia caryophyllata) leaves, stems, and roots (Inoue and Moraes, 2007). The efficiency of eugenol has been observed for several species, such as rainbow trout (Oncorhynchus mykiss; Keene et al., 1998), pacamã (Lophiosilurus alexandri; Ribeiro et al., 2013), Nile tilapia (Oreochromis niloticus; Vidal et al., 2008; Ribeiro et al., 2015b), matrinxã (Brycon cephalus; Barbosa et al.,

Received: October 31, 2017

Accepted: August 1, 2018

*Corresponding author: takatarodrigo@gmail.com

Copyright @ 2018 Sociedade Brasileira de Zootecnia. This is an Open Access article distributed under the terms of the Creative Commons Attribution License (http://creativecommons.org/licenses/by/4.0/), which permits unrestricted use, distribution, and reproduction in any medium, provided the original work is properly cited.
2007; Vidal et al., 2007), pacu (Piaractus mesopotamicus; Gonçalves et al., 2008), lambari (Astyanax altiparanae; Pereira-da-Silva et al., 2009), silver catfish (Rhamdia quelen; Cunha et al., 2010; Gomes et al., 2011), and fat snook (Centropomus parallelus; Souza et al., 2012).

Menthol is an essential oil extracted from plants of the genus Mentha (Patel et al., 2007). This drug may be used for fish anesthesia, as observed for pacu (Gonçalves et al., 2008), tambaqui (Colossoma macropomum; Façanha and Gomes, 2005), fat snook (Souza et al., 2012), dourado (Salminus brasiliensis; Pádua et al., 2010), and Nile tilapia (Simões and Gomes, 2009).

Curimba (Prochilodus lineatus) has social, ecological, and economic importance in South America (Jorge et al., 2011). The species has excellent growth performance and potential for aquaculture (Graeff and Tomaselli, 2011). However, studies on the effects of eugenol and menthol in early juveniles of curimba were not tested yet in curimba. Therefore, the present study aimed to evaluate the efficiency of eugenol and menthol as anesthetics for early juveniles of the species.

\section{Material and Methods}

Early juveniles of curimba were purchased from a commercial hatchery and transported by car to the laboratory 
rearing facilities in Cordeiro, RJ, Brazil $\left(22^{\circ} 01^{\prime} 03.88^{\prime \prime} \mathrm{S}\right.$ and $\left.42^{\circ} 21^{\prime} 24.14 " \mathrm{~W}\right)$. All procedures were carried out according to the international practices for animal use and care under the control of a local ethical committee on animal use (case no. 003/2016).

A total of 150 juveniles of curimba, weighing $4.0 \pm 0.5 \mathrm{~g}$, with a total average length of $8.8 \pm 0.1 \mathrm{~cm}$, were used for anesthetic induction by menthol and eugenol. The juveniles of curimba were acclimated for a period of 30 days in a recirculation system in 120-L water tanks. They were fed three times a day (at 8:00, 12:00, and 17:00 h) a commercially formulated diet containing $400 \mathrm{~g}$ protein $\mathrm{kg}^{-1}$, $350 \mathrm{mg} \mathrm{kg}^{-1}$ vitamin $\mathrm{C}, 80 \mathrm{~g}$ ether extract $\mathrm{kg}^{-1}$, and $100 \mathrm{~g}$ moisture $\mathrm{kg}^{-1}$ (levels and guarantees made available by the manufacturer). The experimental units were cleaned prior to the first and after the last feed for the withdrawal of excreta and food residues. The water quality indicators remained in the range considered adequate for the maintenance of tropical fish species (Arana, 2004). Water temperature was kept at $25.2 \pm 0.8{ }^{\circ} \mathrm{C}$; dissolved and saturated oxygen at $7.0 \pm 0.4 \mathrm{mg} \mathrm{L}^{-1}$ and $86.0 \pm 3.9 \%$, respectively; $\mathrm{pH}$ at $6.7 \pm 0.3$; electric conductivity at $0.6 \pm 0.1 \mu \mathrm{S} \mathrm{cm} \mathrm{cm}^{-1}$; total dissolved solids at $0.3 \pm 0.1 \mathrm{ppt}$; and unionized ammonia nitrogen $\left(\mathrm{NH}_{3}-\mathrm{N}\right)$ at $0.15 \pm 0.03 \mathrm{mg} \mathrm{L} \mathrm{L}^{-1}$. Physical and chemical monitoring of water was carried out using a HI83203-01 Hanna Photometer, HI9146-04 Hanna oxygen meter, and HI98130 Hanna multi-parameter Combo.

The experiments were performed in a completely randomized design, in which the treatments were menthol $\left(20,30,40,50,60,70\right.$, and $\left.80 \mathrm{mg} \mathrm{L}^{-1}\right)$ and eugenol (20, $30,40,50,60$, and $70 \mathrm{mg} \mathrm{L}^{-1}$ ) concentrations. Ten fish randomly chosen were used in each treatment. Eugenol (Escamaforte ${ }^{\circledR}$ ) and menthol (CRQ-1006310100) were first diluted (1:10) in ethanol $98.8 \%$ to reduce their hydrophobic character, and later added to the experimental units in accordance with the predetermined concentrations. Fish feed was suspended for a 24-h period before the anesthetic procedure. The hyperactivity of fish subjected to immersion in an anesthetic should not be attributed to ethanol used as a solvent. Therefore, early juveniles of curimba were subjected to an ethanol $(98.8 \%)$ solution at similar quantity of that used in the highest concentrations of anesthetics to evaluate the possible hyperactivity.

For the induction analysis and recovery from anesthesia, fish were randomly captured one at a time and placed in a 2-L beaker containing the concentration of anesthetic to be tested. The behavioral characteristics of the deep anesthesia (stage 4 of anesthesia) used in this study followed the recommendations suggested by Ross and Ross (2008), basically characterized by loss of equilibrium, absence of swimming, reduction of opercular movements, and responses only to intense tactile stimuli. The non-reaction to stimuli was verified by touching the fish on the side using a glass rod. When the individuals reached the stage 4 of anesthesia, their biometry and weight (model BL320H Shimatzu scale) measurements (total length using a ruler) were carried out to simulate the actual handling conditions in fish farming. For recovery, all individuals were placed in anesthetic-free water in 2-L beakers. To assess the anesthetic recovery stages, the criteria proposed by Hikasa et al. (1986) were adopted. After the experiments, fish from each replicate were pooled and kept in 50-L tanks in a recirculating water system to observe the return to appetite and the survival rate after $96 \mathrm{~h}$.

An ANOVA and the Tukey's test for the comparison of means were performed using the SAS software (Statistical Analysis System, version 8.0). The results of the induction and recovery time were analyzed using a non-linear regression for the function with best adjustment of data.

\section{Results}

Exposure to ethanol solvent did not provoke any behavioral change. Menthol and eugenol concentrations proved efficient in promoting induction at the deep anesthetic phase in early juveniles of curimba. As concentrations increased, there was a decrease $(\mathrm{P}<0.05)$ in the induction and recovery time. Juveniles of curimba did not reach deep anesthesia after $30 \mathrm{~min}(1800 \mathrm{~s})$ of exposure to the $20 \mathrm{mg}$ menthol $\mathrm{L}^{-1}$. Thus, this concentration was withdrawn from the statistical analysis. The longest induction time $(\mathrm{P}<0.05)$ was verified at the lowest concentration of $30 \mathrm{mg}^{\text {menthol L}} \mathrm{L}^{-1}$, whereas the shortest times $(\mathrm{P}<0.05)$ were observed in the 60 to $80 \mathrm{mg}$ menthol $\mathrm{L}^{-1}$ concentrations $(\mathrm{P}<0.05)$. Juveniles subjected to anesthesia showed a recovery time inversely proportional to menthol concentrations, i.e., it was verified that, as the anesthetic concentrations increased, the recovery time decreased $(\mathrm{P}<0.05)$ (Figure 1).

Eugenol proved to be efficient in anesthetizing early juveniles of curimba, with concentrations presenting statistical differences for the time required to induce the deep anesthesia phase (Figure 1). The longest induction time $(\mathrm{P}<0.05)$ occurred at lower concentrations of $20 \mathrm{mg}$ eugenol $\mathrm{L}^{-1}$, whereas the shortest induction time $(\mathrm{P}<0.05)$ occurred at a concentration of $70 \mathrm{mg}$ eugenol $\mathrm{L}^{-1}$. Regarding the recovery period, no difference was detected $(\mathrm{P}>0.05)$ relative to the tested concentration (Figure 1).

In all treatments, the early juveniles of curimba showed a return to appetite in $24 \mathrm{~h}$ after the anesthesia test. After $96 \mathrm{~h}$ following the recovery from anesthesia, a $10 \%$ 

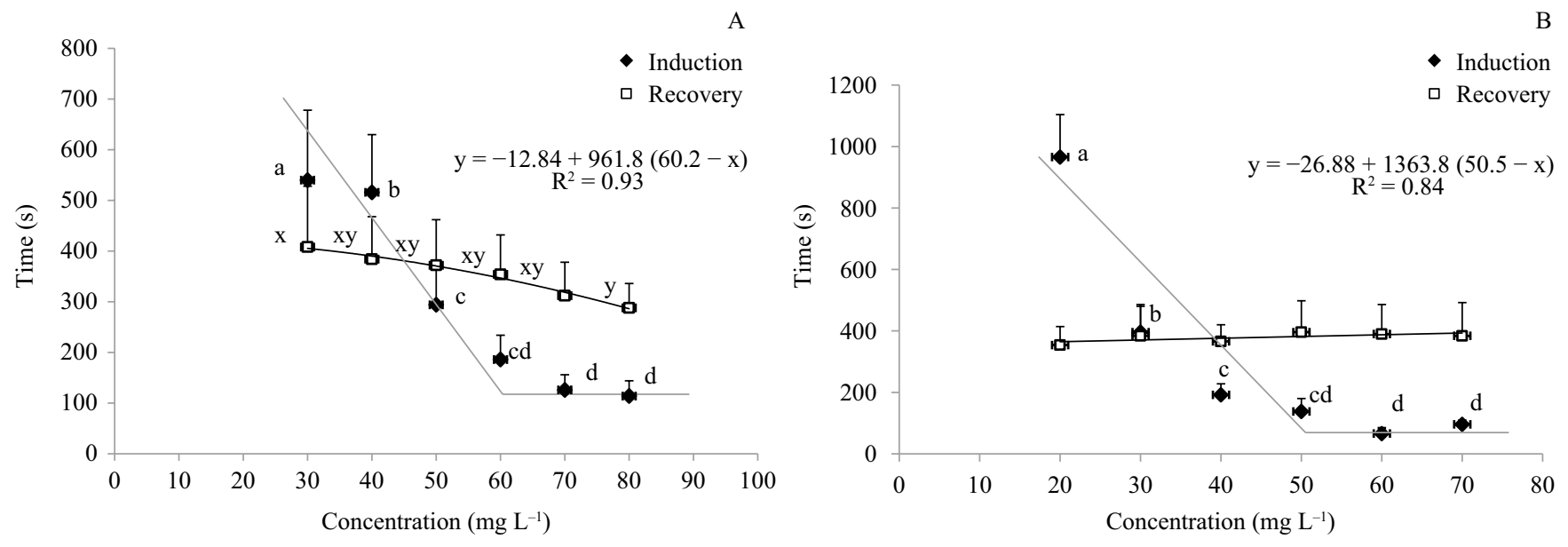

Means followed by the same letters (a-d for induction; $\mathrm{x}-\mathrm{y}$ for recovery) did not differ by Tukey's test $(\mathrm{P}<0.05)$.

Figure 1 - Induction and recovery time to reach anesthesia (seconds) of early juveniles of curimba (Prochilodus lineatus) subjected to menthol (A) and eugenol (B) concentrations.

mortality occurred for $30,50,60$, and $80 \mathrm{mg}$ menthol $\mathrm{L}^{-1}$ concentrations. For eugenol, a 10\% mortality was observed in 20 to $70 \mathrm{mg} \mathrm{L}^{-1}$ concentrations. In our observations, this mortality resulted from fish interactions (bites) and was not directly related to anesthetic toxicity.

\section{Discussion}

Hyperactivity was observed in fish subjected to immersion in an anesthetic and should not be attributed to ethanol, generally used as a solvent, but to the anesthetic itself (Vidal, et al., 2008; Readman, et al., 2013). Therefore, early juveniles of curimba were subjected to ethanol solution; these animals showed no reactions or hyperactivity. The present study provides insights into adequate techniques for the use of the anesthetics menthol and eugenol for sedation of early juveniles of curimba.

The concentrations tested in this study fall within the suggestions given by Marking and Meyer (1985), who considered a good anesthetic as that which induces deep anesthesia from 1 to $3 \mathrm{~min}$ (60 to $180 \mathrm{~s}$ ), and recovery at 5 $\min (300 \mathrm{~s})$. In general, there were differences in methods and fish size during the anesthesia process. Smaller fish have a larger gill surface area ratio in relation to body weight than larger fish and, thus, have a superior area for anesthetic absorption through the gills (Woody et al., 2002; Ross and Ross, 2008). The present study provides information about the use of menthol and eugenol as anesthetics for early juveniles of curimba $(4 \mathrm{~g})$.

The results of the present study demonstrated that the increase in menthol concentrations led to a decrease in induction and recovery times for early juveniles of curimba.
A similar response was observed in $S$. brasiliensis (Pádua et al., 2010), O. niloticus (Mello et al., 2012), and fat snook (Souza et al., 2012). For fat snook, increased menthol concentration did not affect recovery time. Pádua et al. (2010) anesthetized juveniles of $S$. brasiliensis and found that the longest anesthetic induction time was observed at the concentration of $60 \mathrm{mg}$ menthol $\mathrm{L}^{-1}$, and the shortest time was verified at the concentration of $150 \mathrm{mg}$ menthol $\mathrm{L}^{-1}$. For lambari, induction time decreased, and recovery time increased linearly with the increase in the menthol concentration (Pereira-da-Silva et al., 2014). In addition, menthol has an anesthetic effect and attenuates the stress response in lambari; $50 \mathrm{mg} \mathrm{L}^{-1}$ was the most effective concentration for inducing deep anesthesia within $60 \mathrm{~s}$, and was safe up to $360 \mathrm{~s}$ exposure. The $60 \mathrm{mg}$ menthol $\mathrm{L}^{-1}$ concentration suggested for $P$. lineatus showed that animals can reach deep anesthesia within $180 \mathrm{~s}$ and recover $332 \mathrm{~s}$ after being induced.

The concentration suggested in this study for the anesthetic induction of $4 \mathrm{~g}$ curimba was $50 \mathrm{mg}$ eugenol $\mathrm{L}^{-1}$. Concentrations of $20 \mathrm{mg}$ eugenol $\mathrm{L}^{-1}$ provided the longest time for curimba juvenile sedation, more than $30 \mathrm{~min}$. For silver catfish, eugenol concentrations between 20 to $30 \mathrm{mg} \mathrm{L}^{-1}$ induced stage 4 anesthesia within 15 min (900 s) (Cunha et al., 2010). In addition, rapid induction to stage 4 of anesthesia was observed with limited effects on the fish at a concentration of $50 \mathrm{mg}$ eugenol $\mathrm{L}^{-1}$. This value was similar to that suggested by Diemer et al. (2012) for juveniles of jundiá (Rhamdia voulezi). In early life stages of Nile tilapia, with an average weight of 2 and $11 \mathrm{~g}, 50 \mathrm{mg}$ eugenol L ${ }^{-1}$ induced anesthesia within 3 min (Ribeiro et al., 2015b). Pereira-da-Silva et al. (2009) studied the effectiveness 
of eugenol on early juveniles of lambari and found that concentrations between 50 and $150 \mathrm{mg} \mathrm{L}^{-1}$ promoted deep anesthesia in $<3 \mathrm{~min}$; however, mortalities following higher dosages were documented $\left(150 \mathrm{mg} \mathrm{L}^{-1}\right)$.

Previous studies have shown that proper immersion anesthesia may decrease the incidence of adverse effects and lead to a milder recovery (Acerete et al., 2004; Zahl et al., 2009). In the present study, there were no differences in recovery time in early juveniles of curimba anesthetized with eugenol in concentrations from 20 to $70 \mathrm{mg} \mathrm{L}^{-1}$. Eugenol was also effective in inducing deep anesthesia in juveniles (mean weight $=3.31 \mathrm{~g}$ ) of matrinxã (Brycon cephalus). Concentrations of 50-100 mg eugenol $\mathrm{L}^{-1}$ were effective in inducing anesthesia with a relatively fast recovery time (Vidal et al., 2007). For groups of Nile tilapia ranging from 0.02 to $11 \mathrm{~g}$, the recovery time was between 53.07 to $184.31 \mathrm{~s}$. Eugenol is an efficient anesthetic for tambaqui; juveniles exposed to $35-135 \mathrm{mg}$ eugenol $\mathrm{L}^{-1}$ recovered within 350 to $1235 \mathrm{~s}$, respectively (Roubach et al., 2005). In fact, concentrations of 50-100 $\mathrm{mg}$ eugenol $\mathrm{L}^{-1}$ provided a recovery time higher than the ideal (300 s), however, out of the critical range (>600 s) (Marking and Meyer, 1985). Similarly, early juveniles of curimba showed a recovery time of 354 to $390 \mathrm{~s}$.

High survival was observed in juveniles of curimba $96 \mathrm{~h}$ after anesthesia with menthol and eugenol (>90\%); moreover, fish showed return to appetite $24 \mathrm{~h}$ after the procedure. For Nile tilapia between $0.02-11 \mathrm{~g}$, after $24 \mathrm{~h}$ of testing with the eugenol concentrations from 50 to $200 \mathrm{mg} \mathrm{L}^{-1}$, a $100 \%$ survival was observed, and all fish resumed eating (Ribeiro et al., 2015b). Elevated mortality of lambari was observed when fish were exposed to surgical anesthesia using 75 and $100 \mathrm{mg}$ eugenol $\mathrm{L}^{-1}$. The unique safe concentrations for surgical anesthesia in lambari was $50 \mathrm{mg}$ eugenol $\mathrm{L}^{-1}$. However, for deep anesthesia, concentrations of 50 to $125 \mathrm{mg}$ eugenol $\mathrm{L}^{-1}$ resulted in no mortality for the species (Pereira-da-Silva et al., 2009). Generally, 20-70 mg eugenol $\mathrm{L}^{-1}$ resulted in elevated survival and demonstrated the possibility of effective handling of animals and avoiding increased mortality. The mortality observed for early juveniles of curimba after the procedure was a result of fish interaction (bites) and not a direct relation to anesthetic toxicity.

\section{Conclusions}

Menthol and eugenol proved to be efficient in inducing deep anesthetic stages in early juveniles of curimba, and the recommended concentrations are 60 and $50 \mathrm{mg} \mathrm{L}^{-1}$, respectively.

\section{Acknowledgments}

We acknowledge the Programa de Pós-graduação em Aquicultura e Recursos Aquáticos Tropicais of Universidade Federal Rural da Amazônia (UFRA), Coordenação de Aperfeiçoamento de Pessoal de Nível Superior (CAPES), and Fundação de Amparo à Pesquisa do Estado do Rio de Janeiro (FAPERJ), for the financial support. We also thank the Fundação Instituto de Pesca do Estado do Rio de Janeiro (FIPERJ), for the space made available for the development of this research.

\section{References}

Acerete, L.; Balasch, J. C.; Espinosa, E.; Josa, A. and Tort, L. 2004 Physiological responses in Eurasian perch (Perca fluviatilis, 1.) subjected to stress by transport and handling. Aquaculture 237:167-178. https://doi.org/10.1016/j.aquaculture.2004.03.018

Arana, L. 2004. Princípios químicos de qualidade da água em aquicultura. UFSC, Florianópolis.

Barbosa, L. G.; Moraes, G. and Inoue, L. A. K. A. 2007. Respostas metabólicas do matrinxã submetido a banhos anestésicos de eugenol. Acta Scientiarum Biological Science 29:255-260. https://doi.org/10.4025/actascibiolsci.v29i3.474

Bertozi Junior, M.; Diemer, O.; Neu, D. H.; Bittencourt, F.; Boscolo, W. R. and Feiden, A. 2014. Benzocaína e eugenol como anestésicos para juvenis de Pimelodus britskii (mandi-pintado). Revista Brasileira de Ciência Agrária 9:134-138.

Cunha, M. A.; Zeppenfeld, C. C.; Garcia, L. O.; Loro, V. L.; Fonseca, M. B.; Emanuelli, T.; Veeck, A. P. L.; Copatti, C. E. and Baldisserotto, B. 2010. Anesthesia of silver catfish with eugenol: time of induction, cortisol response and sensory analysis of fillet. Ciência Rural 40:2107-2114. https://doi.org/10.1590/S010384782010005000154

Diemer, O.; Neu, D. H.; Bittencourt, F.; Signor, S.; Boscolo, W. R. and Feiden, A. 2012. Eugenol como anestésico para jundiá (Rhamdia voulezi) em diferentes pesos. Semina: Ciências Agrárias 33:14951500. https://doi.org/10.5433/1679-0359.2012v33n4p1495

Façanha, M. F. and Gomes, L. C. 2005. A eficácia do mentol como anestésico para tambaqui (Colossoma macropomum, Characiformes: Characidae). Acta Amazonica 35:71-75. https:// doi.org/10.1590/S0044-59672005000100011

Gomes, D. P.; Chaves, B. W. C.; Becker, A. G. and Baldisserotto, B. 2011. Water parameters affect anaesthesia induced by eugenol in silver catfish, Rhamdia quelen. Aquaculture Research 42:878-886. https://doi.org/10.1111/j.1365-2109.2011.02864.x

Gonçalves, A. F. N.; Santos, E. C. C.; Fernandes, J. B. K. and Takahashi, L. S. 2008. Mentol e eugenol como substitutos da benzocaína na indução anestésica de juvenis de pacu. Acta Scientiarum Animal Science 30:339-344. https://doi.org/10.4025/ actascianimsci.v30i3.1081

Graeff, A. and Tomaselli, A. 2011. Policultivo de carpas com introdução crescente do curimatã (Prochilodus scropha) como espécie principal. REDVET Revista Electónica de Veterinaria 12:1-11.

Hikasa, Y.; Takasa, K.; Ogasawara, T. and Ogasawara, S. 1986. Anesthesia and recovery with tricaine methanesulfonate, eugenol and thiopental sodium in the cap, Cyprinus carpio. Nippon Juigaku Zasshi 48:341-351.

Inoue, L. A. K. A. and Moraes, G. 2007. Óleo de cravo: um anestésico alternativo para o manejo de peixes. Embrapa Amazônia Ocidental, 
Manaus-AM. Available at: <https://www.embrapa.br/web/mobile/ publicacoes/-/publicacao/681655/oleo-de-cravo-um-anestesicoalternativo-para-o-manejo-de-peixes $>$. Accessed on: Aug. 22, 2017.

Jorge, L. C.; Sanchez, S. and Moreira Filho, O. 2011. Chromosomal characterization of Prochilodus lineatus from Paraná River. Corrientes, Argentina. I. B Chromosomes and NOR banding. Cytologia 76:219-222. https://doi.org/10.1508/cytologia.76.219

Keene, J. I.; Noakes, D. I. G.; Moccia, R. D. and Soto, G. C. 1998. The efficacy of clove oil as an anesthetic for rainbow trout, Oncorhynchus mykiss (Walbaum). Aquaculture Research 29:89-101.

Marking, L. L. and Meyer, F. P. 1985. Are better fish anesthetics needed in fisheries? Fisheries, Bethesda 10:2-5.

Mello, R. A.; Costa, L. S.; Okamura, D.; Araújo, F. G.; Ribeiro, P. A. P.; Corrêa, F. M. and Rosa, P. V. 2012. Avaliação de 2-fenoxietanol e mentol como agentes anestésicos em tilápias. Boletim do Instituto de Pesca 38:53-59.

Pádua, S. B.; Pietro, P. S.; Iglesias-Filho, P. S.; Ishikawa, M. M. and Hisano, H. 2010. Mentol como anestésico para dourado (Salminus brasiliensis). Boletim do Instituto de Pesca 36:143-148.

Patel, T.; Ishiuji, Y. and Yosipovitch, G. 2007. Menthol: a refreshing look at this ancient compound. American Academy of Dermatology 57:873-878. https://doi.org/10.1016/j.jaad.2007.04.008

Pereira-da-Silva, E. M.; Oliveira, R. H. F. and Nero, B. D. 2014. Menthol as anaesthetic for lambari Astyanax altiparanae (Garutti \& Britski 2000): attenuation of stress responses. Aquaculture Research 47:1413-1420. https://doi.org/10.1111/are.12599

Pereira-da-Silva, E. M.; Oliveira, R. H. F.; Ribeiro, M. A. R. and Coppola, M. P. 2009. Efeito anestésico do óleo de cravo em alevinos de lambari. Ciência Rural 39:1851-1856. https://doi.org/ 10.1590/S0103-84782009005000127

Readman, G. D.; Owen, S. F., Murrell, J. C. and Knowles, T. G. 2013. Do fish perceive anaesthetics as aversive? Plos One 8:e73773. https://doi.org/10.1371/journal.pone.0073773

Ribeiro, P. A. P.; De Melo, D. C.; Santo, A. H. E.; Silva, W. S.; Santos, A. E. H. and Luz, R. K. 2015a. Tricaine as an anaesthetic for larvae and juveniles of Lophiosilurus alexandri, a carnivorous freshwater fish. Aquaculture Research 46:1788-1792. https://doi.org/10.1111/ are. 12316

Ribeiro, P. A. P.; Miranda-Filho, K. C.; De Melo, D. C. and Luz, R. K. 2015b. Efficiency of eugenol as anesthetic for the early life stages of Nile tilapia (Loreochromis niloticus). Anais da Academia Brasileira de Ciências 87:529-535. https://doi.org/10.1590/00013765201520140024

Ribeiro, P. A. P.; Miranda Filho, K. C.; Melillo Filho, R.; Santos, A. E. H.; Silva, W. S.; Rodrigues, L. A. and Luz, R. K. 2013. Efeito anestésico do eugenol em juvenis de pacamã. Pesquisa Agropecuária Brasileira 48:1136-1139. https://doi.org/10.1590/ S0100-204X2013000800048

Ross, L. G. and Ross, B. 2008. Anaesthetic and sedative techniques for aquatic animals. 3rd. ed. Blackwell Science, Oxford.

Roubach, R.; Gomes, L. C.; Fonseca, F. A. L. and Val, A. L. 2005. Eugenol as an efficacious anaesthetic for tambaqui, Colossoma macropomum (Cuvier). Aquaculture Research 36:1056-1061. https://doi.org/10.1111/j.1365-2109.2005.01319.x

Simões, L. N. and Gomes, L. C. 2009. Eficácia do mentol como anestésico para juvenis de tilápia-do-nilo (Oreochromis niloticus). Arquivos Brasileiros Medicina Veterinária Zootecnia 61:613-620. https://doi.org/10.1590/S0102-09352009000300014

Souza, R. A. R.; Carvalho, C. V. A.; Nunes, F. F. N.; Scopel, B. R.; Guarizi, J. D.; Tsuzuki, M. Y. 2012. Efeito comparativo da benzocaína, mentol e eugenol como anestésicos para juvenis de robalo peva. Boletim Instituto de Pesca 38:247-255.

Vidal, L. V. O.; Albinati, R. C. B.; Albinati, A. C. L.; Lira, A. D.; Almeida, T. R. and Santos, G. B. 2008. Eugenol como anestésico para a tilápia-do-nilo. Pesquisa Agropecuária Brasileira 43:10691074. https://doi.org/10.1590/S0100-204X2008000800017

Vidal, L. V. O.; Furuya, W. M.; Graciano, T. S.; Schamber, C. R.; Silva, L.; C. R.; Santos, L. D. and Souza, S. R. 2007. Eugenol como anestésico para juvenis de matrinxã (Brycon cephalus). Revista Brasileira de Saúde Produção Animal 8:335-342.

Walsh, C. T. and Pease, B. C. 2002. The use of clove oil as an anesthetic for the long finned eel, Anguilla reinhardtii (Steindachner). Aquaculture Research 33:627-635.

Woody, C. A.; Nelson, J. and Ramstad, K. 2002. Clove oil as an anesthetic for adult sockeye salmon: field trails. Journal of Fish Biology 60:340-347.

Zahl, I. H.; Kiessling, A.; Samuelsen, O. B. and Hansen, M. K. 2009. Anaesthesia of Atlantic cod (Gadus morhua): effect of preanaesthetic sedation, and importance of body weight, temperature and stress. Aquaculture 295:52-59. https://doi.org/10.1016/j. aquaculture.2009.06.019 